\title{
PENGEMBANGAN MEDIA CHEM DICE PADA MATERI TATA NAMA SENYAWA DI MAN 1 BANJARMASIN
}

\section{The Development of Chem Dice Media on Compound Nomenclature Material in MAN 1 Banjarmasin}

\author{
Siti Nurimah*, Novrian Dony, Herlina Apriani \\ Program Studi Pendidikan Kimia Fakultas Keguruan dan Ilmu Pendidikan \\ Universitas Islam Kalimantan (Uniska) Muhammad Arsyad Al Banjari, \\ Banjarmasin \\ email: nurimahashter07@gmail.com
}

\begin{abstract}
Abstrak. Penelitian ini bertujuan untuk menguji kelayakan media chem dice yang layak digunakan sebagai media pembelajaran. Media chem dice dapat menjadi bahan pertimbangan oleh guru-guru kimia sebagai sumber alternatif dalam melaksanakan pembelajaran, khususnya untuk mempermudah siswa dalam memahami materi tata nama senyawa. Jenis penelitian ini adalah penelitian pengembangan (Research and Development) menurut teori Sugiyono. Media chem dice dihasilkan melalui langkah- langkah proses ( $\mathrm{R} \&$ D), meliputi tahap potensi dan masalah, pengumpulan data, desain produk, validasi desain produk, revisi desain, uji coba produk, revisi produk, uji coba pemakaian dan revisi produk final. Hasil uji kelayakan media chem dice meliputi kelayakan isi, kelayakan sajian, kelayakan bahasa, dan kelayakan kegrafisan oleh validator mendapatkan skor rata-rata sebesar 95,83\% dengan kriteria sangat layak. Pada uji coba produk mendapatkan rata-rata skor sebesar 17,3 dengan kriteria sangat baik, sedangkan uji coba pemakaian mendapatkan ratarata skor sebesar 15,8 dengan kriteria sangat baik. Berdasarkan hasil penilaian diatas maka dapat disimpulkan bahwa media chem dice layak digunakan sebagai media pembelajaran.
\end{abstract}

Kata Kunci : Chem Dice, Kelayakan Media, Tata Nama Senyawa

\begin{abstract}
This study aimed to test the feasibility of chem dice media which was suitable for use as a learning media. Chem dice media can be taken into consideration by chemistry teachers as an alternative source in carrying out learning, especially to make it easier for students to understand the compound nomenclature material. The type of this research was development research (Research and Development) according to Sugiyono's theory. Chem dice media were generated through process steps $(R \& D)$, including potential and problem stages, data collection, product design, product design validation, design revision, product testing, product revision, usage trials and final product revisions. The results of the feasibility test for chem dice media include content feasibility, presentation feasibility, language feasibility, and graphic feasibility by the validators got an average score of $95.83 \%$ with very feasible
\end{abstract}


criteria. In the product trial, it got an average score of 17.3 with very good criteria, while the usage trial obtained an average score of 15.8 with very good criteria. Based on the results of the above assessment, it can be concluded that the chem dice media is suitable for use as a learning media.

Keywords : Chem Dice, Media Feasibility, Compound Nomenclature

\section{PENDAHULUAN}

Pondasi kehidupan suatu bangsa adalah pendidikan, semakin maju pendidikan maka semakin terarah kesejahteraan masyarakat bangsa tersebut (Parmawati dkk, 2019). Pendidikan merupakan suatu upaya mendewasakan manusia dalam proses perubahan sikap dan perilaku seseorang melalui proses pembelajaran. Pembelajaran adalah suatu proses dalam membantu siswa agar dapat belajar dengan baik. Hal ini didukung oleh penelitian Septiani (2017) yang mengungkapkan bahwa proses perubahan ke arah yang lebih baik terjadi karena adanya interaksi antara guru dan siswa yang disebut dengan pembelajaran. Salah satu contoh pembelajaran yang sulit dipahami oleh siswa, sebab sifatnya yang hafalan adalah pelajaran kimia di Sekolah Menengah atas (SMA) khususnya materi tata nama senyawa. Menurut Susanti (2014) bahwa sebanyak 43,33\% materi yang sulit dipahami karena banyak hafalan adalah materi tata nama senyawa.

Berdasarkan hasil wawancara dengan guru kimia kelas X MAN 1 Banjarmasin, diperoleh informasi bahwa materi tata nama senyawa sulit dipahami siswa, karena siswa perlu menghafal kembali nama-nama unsur beserta lambangnya, menentukan bilangan oksidasi baik unsur logam maupun non logam, sehingga banyak terjadi kesalahan dalam menentukan nama suatu senyawa maupun rumus molekul. Hal ini didukung oleh penelitian Helfiana (2016) yang mengungkapkan bahwa materi tata nama senyawa kimia mempunyai tingkat kesulitan yang cukup tinggi, ia memiliki banyak aturan ketika memberikan nama atau membuat rumus kimia suatu senyawa. Adapun media pembelajaran yang sering digunakan adalah buku paket dan power point, sehingga membuat siswa tidak tertarik untuk belajar. Berdasarkan uraian diatas, maka peneliti menarik kesimpulan bahwa penyebab kurangnya minat belajar siswa pada materi tata nama senyawa adalah kurangnya media pembelajaran yang dapat mengaktifkan siswa untuk belajar serta alokasi waktu belajar kimia yang cukup lama sekitar 2-3 jam tanpa ada di sisipkan media dalam bentuk permainan, sehingga belajar menjadi tidak menarik. Biasanya siswa sudah mulai bosan dan tidak fokus belajar ketika telah melewati 1 jam pelajaran. Hal ini berpotensi bahwa saat latihan soal siswa sudah mulai jenuh karena terlalu lama menerima materi. Banyak cara yang dapat dilakukan guru agar tercapainya tujuan pembelajaran. Salah satunya yang terbaik adalah menggunakan media pembelajaran dalam bentuk permainan (Gomulya \& Iswendi, 2018).

Berdasarkan hasil wawancara dengan guru kimia kelas X MAN 1 Banjarmasin, diperoleh informasi bahwa materi tata nama senyawa sulit dipahami siswa, karena siswa perlu menghafal kembali nama-nama unsur beserta lambangnya, menentukan bilangan oksidasi baik unsur logam maupun non logam, sehingga banyak terjadi kesalahan dalam menentukan nama suatu senyawa maupun rumus molekul. Hal ini didukung oleh penelitian Helfiana (2016) yang mengungkapkan bahwa materi tata nama senyawa kimia 
mempunyai tingkat kesulitan yang cukup tinggi, ia memiliki banyak aturan ketika memberikan nama atau membuat rumus kimia suatu senyawa. Adapun media pembelajaran yang sering digunakan adalah buku paket dan power point, sehingga membuat siswa tidak tertarik untuk belajar. Berdasarkan uraian diatas, maka peneliti menarik kesimpulan bahwa penyebab kurangnya minat belajar siswa pada materi tata nama senyawa adalah kurangnya media pembelajaran yang dapat mengaktifkan siswa untuk belajar serta alokasi waktu belajar kimia yang cukup lama sekitar 2-3 jam tanpa ada di sisipkan media dalam bentuk permainan, sehingga belajar menjadi tidak menarik. Biasanya siswa sudah mulai bosan dan tidak fokus belajar ketika telah melewati 1 jam pelajaran. Hal ini berpotensi bahwa saat latihan soal siswa sudah mulai jenuh karena terlalu lama menerima materi. Banyak cara yang dapat dilakukan guru agar tercapainya tujuan pembelajaran. Salah satunya yang terbaik adalah menggunakan media pembelajaran dalam bentuk permainan (Gomulya \& Iswendi, 2018).

\section{METODE PENELITIAN}

Penelitian dilakukan di MAN 1 Banjarmasin pada tanggal 02 - 14 Maret 2020. Populasinya adalah semua siswa - siswi kelas X dengan sampel kelas X MIA 1 . Penelitian ini merupakan penelitian R\&D (Research and Development) dengan desain yang menggariskan pada langkah pengembangan 1-9 menurut Sugiyono (2016) meliputi tahap potensi dan masalah, pengumpulan data, desain produk, validasi desain produk, revisi desain produk, uji coba produk, revisi produk, uji coba pemakaian dan revisi produk final. Teknik analisis data yang digunakan adalah deskriptif kualitatif, pada teknik analisis data skor hasil validasi diukur menggunakan skala Guttman.

Tabel 1. Skala Guttman (Riduwan,2012)

\begin{tabular}{cc}
\hline Jawaban & Nilai \\
\hline Tidak & 1 \\
Ya & 2 \\
\hline
\end{tabular}

Skor yang diperoleh oleh validator diolah dengan menggunakan teknik analisis deskriptif dalam bentuk persentase. Rumus yang digunakan adalah:

$$
\text { Persentase }=\frac{\sum \text { skor penilaian angket }}{\sum \text { skor mksimum }} \times 100 \%
$$

Persentase hasil validasi yang diperoleh kemudian dikategorikan berdasarkan kriteria menurutSudjana (2013) seperti pada tabel 2. 
Tabel 2. Kriteria penilaian kelayakan media chem dice (Sudjana, 2013)

\begin{tabular}{ccc}
\hline Skor $(\%)$ & Kriteria & Kategori \\
\hline $81-100$ & Sangat layak & Tidak perlu revisi \\
$66-80$ & Layak & Tidak perlu revisiPerlu \\
$56-65$ & Kurang layak & revisi \\
$\leq 55$ & Sangat tidak layak & Perlu revisi \\
\hline
\end{tabular}

Untuk menganalisis respon siswa tersebut digunakan kriteria penilaian respon siswa seperti terdapatpada tabel 3 dan 4 berikut.

Tabel 3. Kriteria penilaian respon siswa terhadap media chem dice

\begin{tabular}{cl}
\hline \multicolumn{1}{c}{ Skor } & \multicolumn{1}{c}{ Kriteria } \\
\hline $9-10$ & Sangat kurang \\
$11-12$ & Kurang \\
$13-14$ & Cukup \\
$15-16$ & Baik \\
$17-18$ & Sangat baik \\
\hline
\end{tabular}

Tabel 4. Kriteria penilaian respon siswa terhadap pembelajaran menggunakan media

\begin{tabular}{cc}
\hline Skor & Kriteria \\
\hline $8-10$ & Cukup \\
$11-13$ & Baik \\
$14-16$ & Sangat \\
& baik \\
\hline
\end{tabular}

\section{HASIL PENELITIAN DAN PEMBAHASAN \\ Tahap Potensi dan Masalah}

Berdasarkan hasil wawancara dengan guru kimia kelas X MAN 1 Banjarmasin, diperoleh informasi bahwa materi tata nama senyawa sulit dipahami siswa, karena siswa perlu menghafal kembali nama-nama unsur beserta lambangnya, menentukan bilangan oksidasi baik unsur logam maupun non logam, sehingga banyak terjadi kesalahan dalam menentukan nama suatu senyawa maupun rumus molekul.

Adapun penyebab lainnya adalah media pembelajaran yang digunakan hanya buku paket dan power point tanpa disisipkan media yang dapat mengaktifkan siswa untuk belajar khususnya pada saat latihan soal sehingga membuat kurangnya minat belajar siswa dan alokasi waktu belajar yang cukup lama sekitar 2-3 jam membuat siswa menjadi bosan dan tidak fokus belajar sehingga belajar menjadi tidak menarik dan sulit dipahami. Hal serupa juga disampaikan oleh penelitian dari Mahmudah, dkk (2019) yang menyatakan bahwa pada umumnya mata pelajaran kimia adalah mata pelajaran yang sulit dipahami dan membosankan karena banyak hafalan dan menghitung, sehinggamembutuhkan daya ingat, kreatifitas tinggi. 


\section{Tahap Pengumpulan Data}

Berdasarkan analisis di MAN 1 Banjarmasin pengumpulan data dilakukan dengan meanganalisa proses pembelajaran, keadaan sekolah, sarana dan prasarana yang ada disekolah, kurikulum sekolah serta karakteristik siswa. Pada tahap ini peneliti mencari informasi dari guru tentang materi apa yang diajakan berikut dengan pertanyaanpertanyaan seperti apa yang biasa gurukeluarkan pada saat latihan soal agar tidak terjadi miskonsepsi. Seperti yang telah disampaikan oleh Halim dkk, (2017) bahwa pelajaran kimia juga dapat berakibat fatal, terlihat dari konsep-konsep kimia umumnya adalah diajarkan dari yang sederhana ke kompleks dari yang mudah kesukar agar siswa lebih mudah memahami konsep kimia. Media chem dice yang ingin dihasilkan adalah media yang didesain sebaik- baiknya sehingga siswa tertarik untuk mencoba.

\section{Tahap Desain Produk}

Desain media chem dice terdiri dari lima jenis dadu, yaitu dua dadu kation, dua dadu anion, satu dadu campuan antara rumus dan nama senyawa serta peraturan permainan media chem dice. Bentuk media chem dice kotak persegi yang di bagi menjadi 6 bagian. Warna setiap dadu pun berbeda, dadu kation berwarna merah dan kuning, dadu anion berwarna hijau dan biru sedangkan dadu rumus dan nama senyawa berwarna hitam. Pembagian warna ini dilakukan dengan tujuan siswa dapat membedakan dengan jelas yang mana kation, anion dan rumus/nama senyawa agar tidak tertukar atau salah melempar ketika permainan dimulai. Ukuran media chem dice yaitu, panjang $25 \mathrm{~cm}$ lebar $25 \mathrm{~cm}$. Jarak soal dengan setiap bagian dadu memiliki ukuran masing-masing $2 \mathrm{~cm}$ seperti pada gambar berikut.

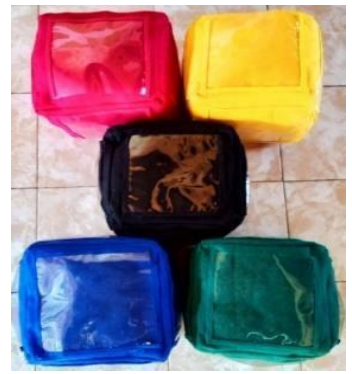

Gambar 1. Desain Media Chem Dice

Bahan utama dari media chem dice ini adalah kain flannel dan dakron. Kain flannel dipilih sebab warnanya yang mencolok, teksturnya halus dan tidak mudah rusak. Sedangkan dakron dipilih sebagai bahan isian sebab tahan lama, tidak keras dan teksturnya yang lebih empuk sehingga dadu lebih mudah untuk memantul. Selain kain flannel dan dakron, bahan lain yang digunakan adalah plastik mika dan kertas. Alat yang digunakan untuk membuat media chem dice adalah mesin jahit, printer, dan gunting. Chem dice sebagai media pembelajaran pada materi tata nama senyawa dapat digunakan berulang kali karena perangkat permainan dibuat sedemikian rupa memiliki keawetan dan ketahanan, yang perlu di ganti hanya pada bagian soalnya saja karena 
sistemnya yang bisa di cabut dan di pasang dengan soal yang baru.

Pemilihan desain pada dadu ini terlebih dahulu perlu di pertimbangkan, untuk siapa dan di tingkat sekolah apa media permainan chem dice ini akan di terapkan. Sesuai di tingkat siswa siswi MAN 1 Banjarmasin, peneliti memilih desain dengan kombinasi berbagai warna cerah, tujuannya agar siswa lebih tertarik, semangat dan senang saat melakukan pembelajaran dengan media permainan chem dice khususnya pada saat latihan soal. Soal berisi unsur-unsur yang terdapat pada sistem periodik salah satunya seperti golongan IA, IIA, $\mathrm{Zn}^{2+}$ dan $\mathrm{Al}^{3+}$ yang kelimpahannya banyakterdapat di alam serta ion terner yang sering muncul di setiap latihan soal pada buku, salah satunya yaitu logam-logam, seperti tembaga, nikel, dan emas (Rahayu, 2009). Tujuannya agar siswa dapat mengingat dengan mudah dan paham dengan materi tata nama senyawa yang dipelajari. Penamaan ini meliputi senyawa biner (logam dan nonlogam), senyawa terner serta senyawa asam basa. Ukuransoal yang terdapat pada media yaitu, panjang 18 $\mathrm{cm}$ lebar $17 \mathrm{~cm}$.

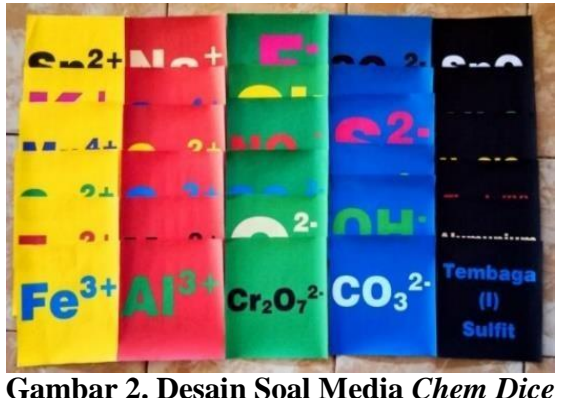

Soal di desain warna warni agar dapat menarik perhatian siswa sehingga siswa menjadi lebih fokus dan lebih tertarik daripada hanya menggunakan satu warna saja, untuk mencapai suasana yangmenarik dan dapat diterima oleh siswa, maka dirancanglah sebuah peraturan permainan. Peraturan permainan media chem dice dibuat sebagai berikut :

1) Guru membagi siswa menjadi 2 kelompok besar

2) Guru meminta perwakilan 1 siswa dari setiap kelompok untuk maju kedepan melempardadu kation dan anion yang ditentukan oleh guru

3) Lalu siswa tersebut menentukan rumus dan nama senyawa dari dadu kation dan anion yangterpasang

4) Siswa yang menjawab dengan cepat dan benar akan melempar dadu kembali yang berisirumus dan nama senyawa, kemudian siswa menentukan rumus/nama senyawa yang sesuai

5) Bagi siswa yang lebih dulu menjawab semua pertanyaan dengan cepat dan tepat mendapat2 poin

\section{Tahap Validasi Desain Produk}

Media chem dice yang divalidasi oleh validator diajukan melalui instrumen angket. Hasil angket oleh validator sebelumnya sudah 2 kali mengalami perbaikan 
sampai media chem dice ini layak digunakan sebagai media pembelajaran. Berikut adalah diagram aspek penilaian media chem dice.

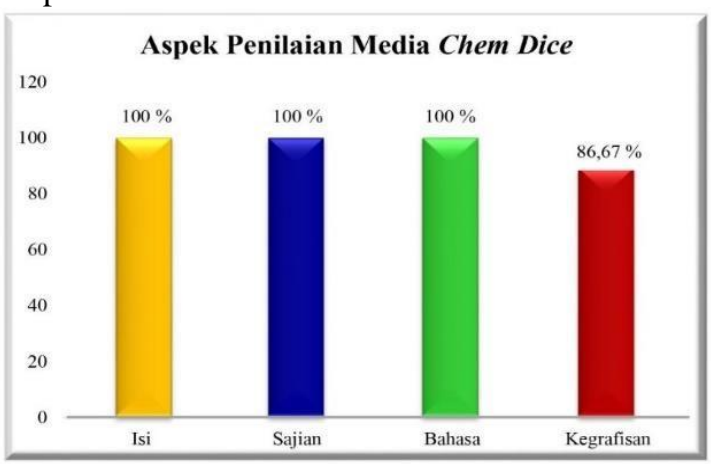

Gambar 3. Persentase Hasil Validasi Media Chem Dice Pada Setiap Aspek Penilaian Oleh 3 Orang Validator

Berdasarkan gambar 3 hasil penilaian terkecil terletak pada aspek kegrafisan dengan rata-rata $86,67 \%$. Hal ini terjadi karena jenis font tulisan yang tidak mudah dibaca, kesesuaian warna background serta tata letak antara tulisan dan dekorasi yang kurang proporsional. Sedangkan pada aspek isi, sajian dan bahasa mendapat nilai tinggi dengan rata-rata $100 \%$.

Penilaian dari ke 4 aspek tersebut, kemudian di konversikan melalui skor angket media chem dice oleh 3 validator yang ahli dalam bidangnya yaitu 1 dari dosen pendidikan kimia dan 2 dari guru mata pelajaran kimia, sehingga didapat hasil dari validator I yaitu sebesar 93,75\% dengan kriteria sangat layak. Kemudian hasil validasi dari validator II mendapatkan nilai sebesar 96,87\% dengan kriteria sangat layak serta hasil validasi oleh validator III sebesar 96,87\% dengan kriteria sangat layak. Sehingga dapat disimpulkan rata-rata skor yang diperoleh adalah sebesar 95,83\% dengan kriteria sangat layak.

\section{Tahap Revisi Desain Produk}

Setiap pemilihan jawaban angket harus dinyatakan dengan komentar/saran, ratarata validator menyarankan bahwa jenis dan ukuran font pada soal serta peraturan permainan diganti yang lebih tebal atau bisa memakai dengan jenis font Swis721 Blk $B T$, terlihat pada gambar 4 dan 5 .

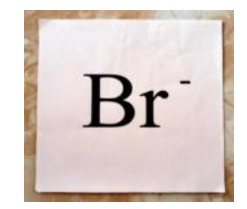

Sebelum di revisi

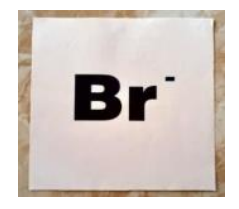

Sesudah di revisi

\section{Gambar 4. Desain Soal pada Media Chem Dice}




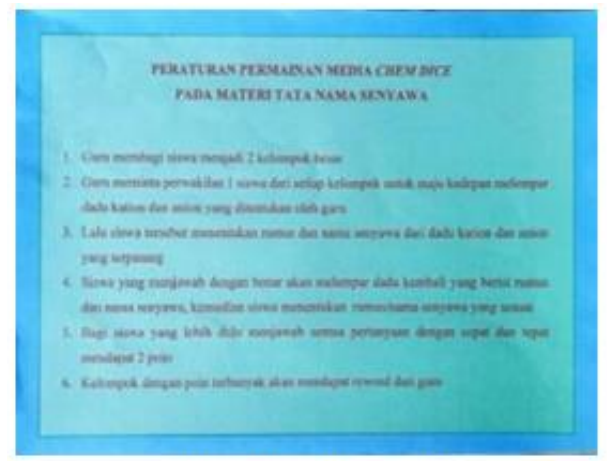

Sebelum di revisi

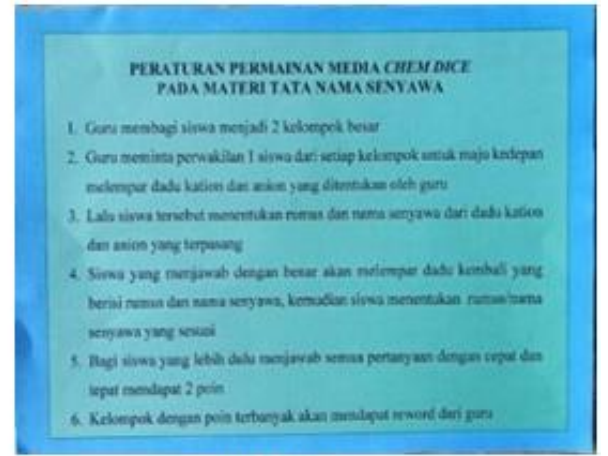

Sesudah di revisi

Gambar 5. Desain Peraturan Permainan Media Chem Dice

\section{Tahap Uji Coba Produk}

Data didapat dari uji coba pada siswa kelas XI MIA 1 di MAN 1 Banjarmasin yang berjumlah 15 orang. Penentuan uji coba produk ini berdasarkan pendapat Sadiman, dkk (2010) bahwa media perlu di cobakan pada 10 sampai 20 siswa yang dapat mewakili populasi target, karena jika kurang dari 10 orang siswa maka data yang didapat kurang mempresentasikan populasi target. Hasil uji coba produk meliputi data hasil angket respon siswa terhadap media, angket berisi 9 pernyataan. Seperti pada gambar berikut.

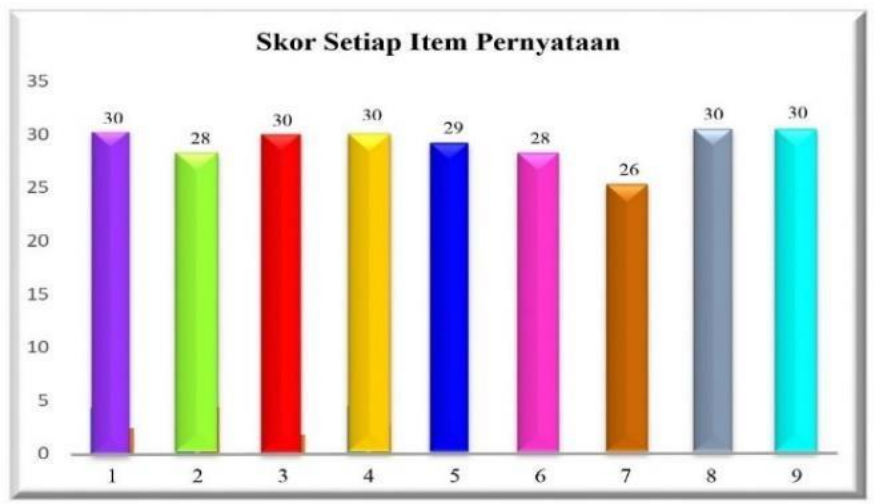

Gambar 6. Rekapitulasi Skor Setiap Item Pernyataan Angket Respon Siswa Terhadap Media

Selain rekapitulasi skor item pada setiap pernyataan, berikut adalah diagram persentase skor yangdidapatkan dari analisis data. 


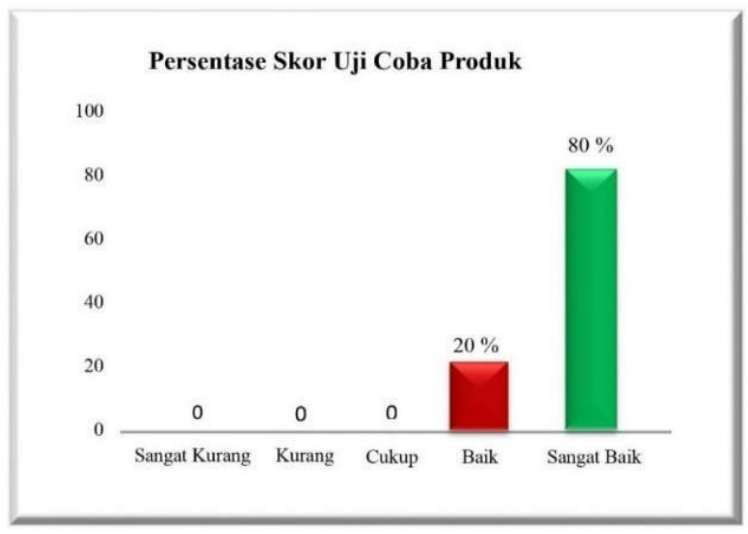

Gambar 7. Diagram Persentase Skor Angket Respon Siswa Terhadap Media Chem Dice

Gambar 7 menunjukkan bahwa $80 \%$ siswa memberikan respon sangat baik terhadap media chem dice, hanya saja ada $20 \%$ siswa memberikan respon baik, Artinya, pada tahap ini terjadi peningkatan, terbukti siswa pada tahap uji coba produk ini memberikan respon positif terhadap media chem dice yang dikembangkan untuk materi tata nama senyawa. Berdasarkan data dari hasil angket uji coba produk yang didapat juga membuktikan bahwa, ada 12 siswa menyatakan kriteria sangat baik dengan nilai rata-rata sebesar 17,8 dan ada 3 siswa yang menyatakan kriteria baik dengannilai rata-rata sebesar 15,3. Maka didapat rata-rata perolehan dari nilai angket seluruh siswa adalah 17,3 yang masuk pada kriteria sangat baik.

Tahap Revisi Produk

Media direvisi berdasarkan respon siswa terhadap angket uji coba produk seperti pada gambar 8 dan 9 .

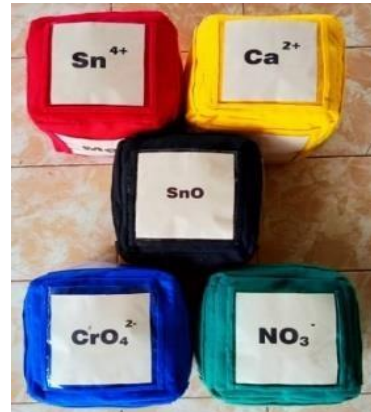

Sebelum di revisi

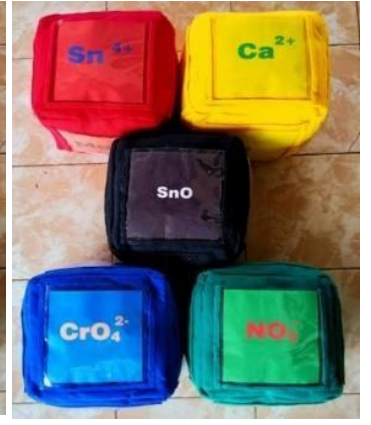

Sesudah di revisi

Gambar 8. Desain Background dan Warna Soal Media Chem Dice 


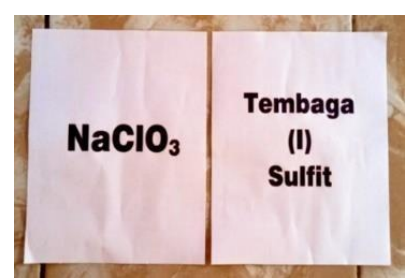

Sebelum di revisi

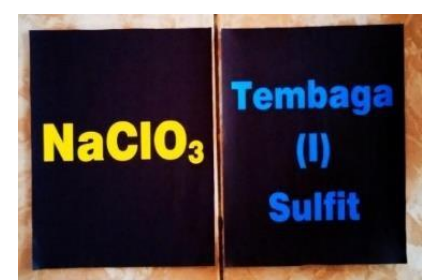

Sesudah di revisi

Gambar 9. Desain Soal Dadu Rumus/Nama Senyawa

\section{Tahap Uji Coba Pemakaian}

Tahap uji coba pemakaian ini dilakukan pada seluruh siswa kelas X MIA 1 di MAN 1 Banjarmasin berjumlah 29 orang untuk mengetahui kalayakan media chem dice yang dikembangkan. Saat pengisian angket ada 2 orang siswa yang tidak hadir karena sakit. Penggunaanmedia chem dice digunakan setelah materi tata nama senyawa selesai disampaikan di kelas tepatnya saat latihan soal pada setiap pertemuan, dengan membagi siswa menjadi 2 kelompok besar dalam bentuk lingkaran. Hasil instrumen penelitian berupa angket respon siswa terhadap pembelajaran yang berisi 8 pernyataan. Seperti pada gambar berikut.

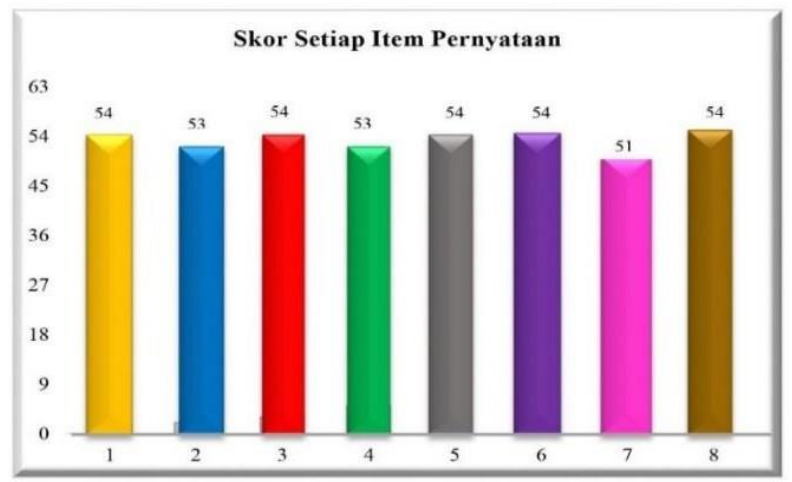

Gambar 10. Rekapitulasi Skor Setiap Item Pernyataan Angket Respon Siswa Terhadap Pembelajaran Menggunakan Media Chem Dice

Penelitian ini dilakukan 3 kali pertemuan dibulan Maret 2020 dengan alokasi waktu setiap pertemuan $3 \times 45$ menit. Saat penggunaan di kelas siswa sangat antusias dalam menggunakan mediaini. Menurut siswa penggunaan media chem dice membuat mereka menjadi lebih tertantang dan ingin terus mengerjakan. Hal ini terbukti dari pernyataan bahwa sesuai dengan karakteristik siswa yaitu siswa usia 7-18 tahun cenderung menyukai media permainan dalam kegiatan pembelajaran (Wahyuni dkk, 2016). Siswa memberikan respon yang baik terhadap media chem dice yang dipakai pada kegiatan pembelajaran tata nama senyawa khususnya pada saat latihan soal, ditunjukan bahwa ada 27 siswa yang semuanya menyatakan bahwa media chem dice sangat baik dengan rata-rata perolehan skor siswa adalah 15,8 dan berikut adalah 
persentase skor angket uji coba pemakaian.

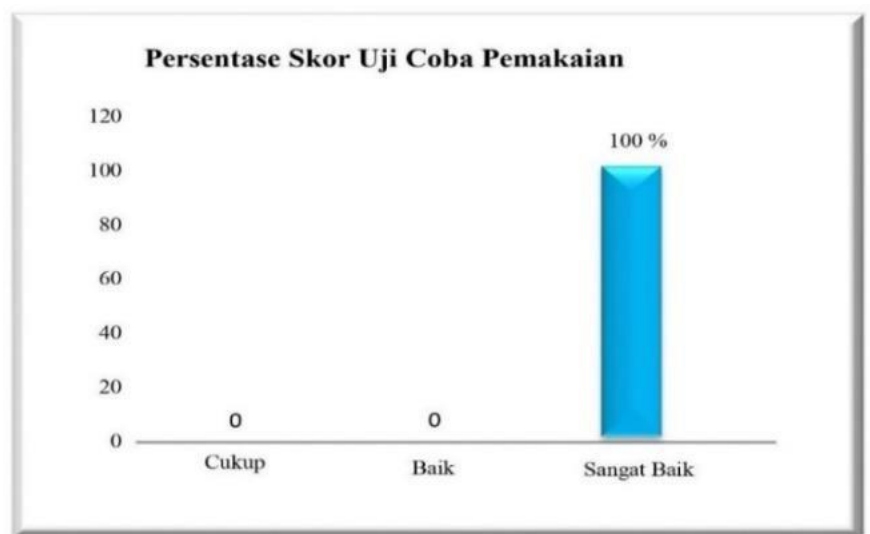

Gambar 11. Diagram Persentase Skor Angket Respon Siswa Terhadap Pembelajaran Menggunakan Media Chem Dice

\section{Tahap Revisi Produk Akhir}

Adapun komentar dan saran yang berkenaan dengan media chem dice yang telah diuji cobakan akan dijadikan bahan pertimbangan untuk menyempurnakan media pembelajaran chem dice sehingga produk pengembangan yang dihasilkan menjadi semakin baik. Jadi siswa tersebut menyarankan untuk memperbesar sedikit lagi tulisan pada soal agar semua siswa dapat melihat pertanyaan dengan jelas dan bisa mencoba untuk mengerjakannya membantu satu sama lain pada masing-masing kelompok. Dapat dilihat pada gambar 12 .

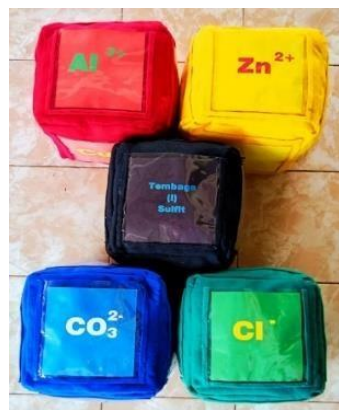

Sebelum di revisi

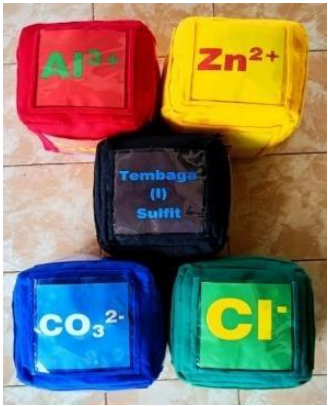

Sesudah di revisi

\section{Gambar 12. Desain Soal Media Chem Dice Tahap Akhir}

Serupa dengan penelitian yang di kemukakan oleh Sakinah \& Iswendi (2018) bahwa Permainan dapat meningkatkan motivasi siswa dan mendorong siswa saling membantu satu dengan yang lainnya sehingga adanya interaksi. 


\section{SIMPULAN}

Media chem dice yang dikembangkn layak digunakan sebagai media pada materi Tata Nama Senyawa di MAN 1 Banjarmasin, dapat ditunjukkan dari hasil validasi diperoleh persentase penilaian rata-rata sebesar 95,83\% dengan kriteria sangat layak. Selain itu, didukung dengan rata-rata skor respon siswa pada uji coba produk sebesar 17,3 dan pada uji coba pemakaiansebesar 15,8 dengan kriteria sangat baik.

\section{DAFTAR RUJUKAN}

Gomulya, D.S \& Iswendi. (2018). Pengembangan Ludo Word Game (LWG) Kimia sebagai Media Chemo-Edutainment (CET) pada Materi Sistem Koloid Kelas XI SMA/MA. Jurnal Menarallmu, 12(12), 19-29.

Halim, A.M., Husain, H \& Sugiarti. (2017). Analisis Miskonsepsi Siswa Kelas X MIA 4 SMA Negeri 1 Pinrang Pada Materi Ikatan Kimia Menggunakan Three-Tier Test. Prosiding Seminar Nasional Kimia UNY, 37-54.

Hamalik, O. (1992). Psikoligi Belajar Mengajar. Bandung: Sinar Baru

Helfiana, M. (2016). Penguasaan Konsep Pada Materi Tata Nama Senyawa Melalui Pembelajaran Berbasis Inkuiri Siswa Kelas X SMAN I Labuhanhaji. Skripsi. Jurusan Pendidikan Kimia Fakultas Tarbiyah dan Keguruan Universitas Islam Negeri Ar-Raniry Darussalam-Banda Aceh.

Irmawati. (2016). Penerapan Media Belajar Alat Peraga Dadu Pada Mata Pelajaran Matematika Untuk Meningkatkan Prestasi Belajar Siswa Kelas II SDN 35 Kampung Sawah Kabupaten Pesisir Selatan. Jurnal Riset Tindakan Indonesia, 1(1), 22-27.

Mahmudah, S., Yuridka, F \& Mashuri, M.T. (2019). Komparasi Pembelajaran Kimia Menggunakan Metode Teams-Games Tournament Dan Team-Assisted Individualization Terhadap Hasil Belajar Pada Materi Ajar Tata Nama Senyawa Kelas X SMA Negeri 12 Banjarmasin. Dalton: Jurnal Pendidikan Kimia dan Ilmu Kimia, 2(1), 16-21.

Parmawati, A., Reffiane, F \& Hadi, H. (2019). Pengaruh Model Pembelajaran Kooperatif Tipe TeamGame Tournament Berbantu Media Ledusa Tema 3. Jurnal Pedagogi dan pembelajaran, 2(3), 394-401.

Rahayu, I. (2009). Praktis Belajar Kimia 1 : Untuk Kelas XII Sekolah Menengah Atas/Madrasah Aliyah. Jakarta: Pusat Perbukuan Depdiknas.

Riduwan. (2012). Skala Pengukuran Variabel-Variabel Penelitian. Bandung: Alfabeta.

Sadiman, A.S., dkk. (2010). Media Pendidikan: Pengertian, Pengembangan dan Pemanfaatannya.

Jakarta: Raja Grafindo Persada.

Sakinah \& Iswendi. (2018). Pengembangan Ludo Word Game Sebagai Media Pembelajaran Pada Materi Minyak Bumi Kelas XI SMA. Jurnal MENARA Ilmu, 12(12), 58-69.

Septiani, V.N. (2017). Pengembangan Roll Spin Accounting Sebagai Media Pembelajaran Akuntansi Pada Kompetensi Dasar Jurnal Penyesuaian Untuk 
Dalton : Jurnal Pendidikan Kimia dan Ilmu Kimia, Volume 4 Nomor 1, Mei 2021

Kelas X Akuntansi Di SMK Koperasi Tahun Ajaran 2017/2018. Skripsi. Jurusan Pendidikan Akuntansi Fakultas Ekonomi Universitas Negeri Yogyakarta.

Sudjana, N. (2013). Dasar-dasar Proses Belajar Mengajar. Bandung: Sinar Baru Algensindo. Sugiyono. (2016). Metode Penelitian \& Pengembangan Research And Development. Bandung:

Alfabeta.

Sukriyanti, F.Z \& Nadiputro, M. (2015). Pengembangan Media Game Kocok Dadu Dalam Pembelajaran Seni Budaya Dan Keterampilan Kelas VI SDN 1 Banjaran Baureno Bojonegoro. Jurnal Pendidikan Seni Rupa, 3(1), 119-125.

Susanti, I.S \& Lutfi, A. (2014). Pengembangan Permainan Tradisional Jamuran Sebagai Media Pembelajaran Tata Nama Senyawa Di Kelas X SMA. Unesa Journal Of Chemical Education, 3(2), 279-287.

Wahyuni, E.S. dan Hidayah, R. (2016). Pengembangan Media Permainan Kartu Quarchem Untuk Melatihkan Keterampilan Berpikir Analitis Siswa Pada Materi Ikatan Kimia Kelas X SMA. In Prosiding Seminar Nasional Kimia dan Pembelajaranya. 